afternoon. Gradually the symptoms of peritonism passed away and in three days she was well again.

CASE 2.- The patient was a woman, aged 34 years, whom I saw two years ago. She was parous but was very desirous to aroid pregnancy again. The catamenia having been regular for some months failed to appear at the expected time. A few days having elapsed she one morning proceeded to syringe herself with hot water, passing the rectal nozzle as far up as possible. She believed it entered her womb. At the first squirt she was seized with frightful pain in the abdomen, was sick, faint, and collapsed, so that a neighbour thought she was dying. Two hours later I found her lying on her back in a state of collapse, groaning with pain in the abdomen which was distended and most acutely tender. The temperature was $102^{\circ} \mathrm{F}$. She soon reacted to stimulants. The uterus was small and there were no signs of pregnancy. She appeared to be entering upon a dangerous attack of peritonitis; on the third day she was, however, practically well.

CASE 3.-A woman, aged 36 years, had had one child, now two years old. She was very anxious to avoid a second pregnancy. Five weeks before I was called to her, after coitus, she injected cold water. She was seized at once with violent pain in the "stomach" and collapsed, so that her husband had been on the point of setting out for me. With the help of brandy in two hours she rallied. Ever since she had had pain in the abdomen. Deep in the left side of the abdomen was a small, very tender tumour. The uterus was anteverted, nonpregnant, and unconnected with the tumour. She complained of frequent attacks of cramping pain in the left side in the neighbourhood of the tumour. A few weeks later she had no more cramp but still said that she had a "lump in the stomach." Two months later she was quite well.

The clinical picture in all these cases is that of a severe shock inflicted on the peritoneum and is exactly comparable to the symptoms of a ruptured viscus, save that there was a rapid rise of temperature. It is very noticeable that in all $m y$ cases the accident happened at the commencement of the injection. I suggest that the uterus was taken nnawares and allowed the fluid to pass into the Fallopian tubes and so by the ostia into the abdominal cavity. In my last two cases the rigor if it occurred was not a striking feature. I cannot accept the explanation cffered for these cases that toxins entered through an abrasion of the surface and caused a rise of temperature. There are very unlikely to be virulent organisms living on the vaginal mucous membrane of non-puerperal women. The whole question is an obscure but very important one. Pathologists might throw much light on the subject by making experiments with Higginson's syringe on the cadaver with a view to discovering whether it is possible to force water from the ordinary vulcanite nozzle or the rectal tube into the abdomen. Abdomens are opened every day and fluids are poured into them, and trocars are driven into them, yet no serious reaction occurs. Why should a few drachms of a weak antiseptic or plain water pumped through the Fallopian tubes produce such grave symptoms? Although quite unable to suggest an alternative I very much doubt whether this, the usual explanation, is competent to account for the severity and suddenness characteristic of the condition.-I am, Sirs, yours faithfully.

Vaughan Pendred, M.D. Durh., F.R.C.S. Eng. Sept. 26th, 1903.

\section{MEDICAL DOCTRINES OF HEREDITY.}

\section{To the Editors of THE LANCET.}

SIRS,--Dr. Reid appears to misunderstand my position somewhat. He has pu forward a certain argument which he told us was " the most convincing one against the popular view" and which has been repeated again and again in letters to THE LANCET. I have endeavoured to point out a fallacy and I believe Dr. Reid will agree that no opinion, however well founded, should be supported by unsound reasoning. He finds fault with me because I only contend that degeneracy from acquired characteristics may occur. I must remind him that $I$ am replying to an argument by which he tries to prove, on theoretical grounds alone, that it is a physical impossibility. My belief is that it is a question to be decided by evidence, and evidence only.

I do not argue that degeneracy is a powerful factor in evolution, or rather in retarding evolution; it is sufficient for my purpose to prove the possibility of its existence. The fundamental idea of my letters that one tendency (degeneracy) may be more than counterbalanced by a stronger tendency (elimination of the unfit) is an exceedingly simple one, and Dr. Peid's elaborate manipulation of figures wil never prove that a strong force cannot overcome a weak one. I am sorry his argument about antelopes is quite unintelligible to me. He says, "A very minute degree of degeneracy of offspring would cause ultimate extinction of the race-how minute may be realised when we consider the slowness of the evolution of a species the individuals of which, as a rule, are not much exposed to deteriorating agencies but die violent deaths." But if a species is not much exposed to deteriorating agencies the resulting degeneracy would be correspondingly small, and slowness of evolution suggests the presence rather than the absence of a retarding factor such as degeneracy.

Dr. Reid also says that the English " have been afflicted by measles probably for thousands of years." It may be so, but it is said that " its separate identity was first shadowed forth by Forestus (1563), but it is to Sydenham (1676) that we owe the full differential diagnosis between measles and smallpox." I It is difficult to believe therefore that his statement has any satisfactory evidence for it. It may be that infectious diseases evolve and die out like higher species of animals, only with far greater rapidity. Dr. Reid says I live "in the futile world of "maybe." I live in a world where many things may be. It is better than one of dogmatism about matters of which I know nothing.

I am, Sirs, yours faithfully,

Sept. 26th, 1903

C. F. SCUDAMORE.

\section{To the Editors of THE LANCET.}

Sirs,-By an inexcusably clumsy expression in my last letter I made it appear as if I took credit for the first discovery of Galton's law of regression towards mediocrity. As you are aware, I tried too late to rectify the blunder and Dr. Niven is entitled to hold me up to derision in consequence. What I meant to say was that it is many years since I first drew attention to the bearing of this law on the inheritance of insanity, \&c. I will not follow Dr. Niven in his wanderings from the point at issue ; and as to his confession of inability to grasp my reasoning I am tempted to quote Dr. Johnson's retort on a similar occasion. But it is necessary to draw attention to a controversial artifice which is not, indeed, rare, but which $I$ have never known to be employed so persistently or with such indifference to the protests of the other side as it is employed by Dr. Reid and Dr. Niven. I refer to their habit of fathering upon their opponents opinions which these opponents do not hold and then gaining a cheap triumph by refuting them. Dr. Wiglesworth has at length wrung a tardy apology from Dr. Niven for one example of this stratagem, but Dr. Reid is more recalcitrant. In one letter ${ }^{2}$ he attributed to me without a shadow of justification an assertion which $I$ had never made and which I immediately repudiated. Any ordinary disputant would have expressed regret. Not so Dr. Reid. In one breath he calls my repudiation a petty personality and a verbal quibble ; in the next he says I am quite right; and then he is positively aggrieved because I repudiate a doctrine which he has gratuitously fathered upon me, and wants to know what business I have to interfere in a discussion with him unless I hold a doctrine which it suits him that I should hold! Knowing by previous experience this practice of Dr. Reid and his "school" I warned your readers in my last letter against it, and sure enough in the very same issue Dr. Reid attributes to me one of the very doctrines which I gave as examples of the sort of absurdity that they might find fathered upon me. The oddest part of the whole affair is that Dr. Niven sees nothing objectionable in this procedure. "If I did, what matter?" says he. Well, to me it matters so much that I withdraw from a discussion conducted by such methods, and I ask what is to be thought of a cause that needs such expedients for its support?

To the question of "M.D." I fear that no satisfactory answer can be given. I know of no book on the subject of heredity with special reference to medical doctrines. The bearing of heredity upon insanity I have been in the habit of dealing with pretty fully in my lectures on this subject and no doubt my colleagues who lecture on the same subject have 
done the same. A very brief and bald résumé of this aspect of heredity is given in my "Text-book of Insanity" and a rather fuller synopsis in the article on Heredity in Hack Tuke's "Dictionary of Psychological Medicine." General biology, with special stress laid upon heredity and reproduction, should no doubt be taught among the " institutes of medicine," but in the overloaded curriculum it would be difficult to find room for it.

On Dr. Wiglesworth's suggestion of a State laboratory for the investigation of scientific problems I look with no favour. Our experience of Government offices is that what is done by them is done badly - is certainly done less well than by private endeavour. The primary business of the State is to prepare for and to conduct its own defence and it is not likely to conduct other affairs more competently than it conducts these. How efficient it is in these primary and essential matters the War Commission shows.

I am, Sirs, yours faithfully,

Sept. 26th, 1903.

Charees Mercier.

\section{To the Editors of THE LANCET.}

SIRS, - If "M.D." has not accepted the hint contained in Dr. C. R. Niven's letter in THE LANCET of Sept. 26th, p. 908, permit me to suggest that he will find exactly what he wants in "Alcoholism : a Study in Heredity" (Fisher Unwin, 1901). The title is perhaps misleading, but "M.D." will find that the first nine chapters explain the subject in very clear language. It is necessary to point out that the subject of "heredity with special reference to medical doctrines" was practically created by the author of the book named and that, therefore, any study of the subject must begin with a perusal of his works. " iv.D. Edin." will find in the same book that the definition he desired was given long ago, and he will be able to judge from a perusal of the work whether Dr. C. Mercier's letters are to be taken as serious contributions to the subject or are to be regarded in the same light as the opposition offered in your correspondence columns, Sirs, to the doctrines of Lister in the early "seventies." I am glad to find that Dr. G. R. Leighton supports my suggestion, ${ }^{1}$ that teaching upon this subject is needed in the medical curriculum. Dr. J. Wiglesworth is welcome to his national laboratory for the experimental study of heredity, but others will prefer to raise their eyes from mere microscopic and laboratory research to a broad study of the process and results of the great experiment which nature has been carry ing on through countless ages in man and the whole animal creation. I venture to think that Dr. Wiglesworth would find this the shorter and surer path to truth in this case. I am, Sirs, yours faithfully,

Florence, Italy, Sept. 28th, 1903. L.AING GORDON.

\section{THE VENTILATION OF DWELLINGS. To the Editors of THE LANCET.}

SIRS,-In The Lancet of Sept. 26th appears a report upon the International Congress of Hygiene and Demography by your Special Sanitary Commissioner and under the head of the Third Section on p. 915 of your journal Mr. Adolphe Smith is reported to have said : "Dr. J. F. J. Sykes has given evidence that in Fngland the authorities proclaimed their failure to solve the problem. They insisted on through ventilation. In other words the rooms were to be purified occasionally by creating such a draught as to render them uninhabitable. This was a clear indication that when inhabited they were insufficiently ventilated."

Permit me, in the first place, to deny that I have given any evidence that in England the authorities have proclaimed their failure to solve the problem of domestic ventilation. In the second place, permit me to assert that in England we have come nearest of any nation to the purification of the air of our dwelling rooms. I make this assertion with the greatest confidence in the support of my colleagues, because English hygienists have realised that the purification of the air of dwelling rooms demands two processes, the one continuous and the other intermittent-namely, ventilation and perflation. Ventilation demands the continuous flow of air through a habitable room in such manner that it may continue to be

1 The Lancet, Sept. 19th, p. 843. ventilated and that the occupants may not feel any appreciable draught. Perflation requires to be of such a forcible kind that the room cannot be occupied with comfort during the period required by the process. The former supplies air for the immediate and continuous requirements of the occupants of the room, the latter forcibly blows away the accumulated products of respiration, combustion, and illumination that deposit themselves upon the various surfaces and in the numerous interstices of the contents of the room. Perflation is the object of the peculiarly English demand that houses, dwellings, and inhabited rooms should be so constructed as to be capable of "through ventilation." It is the object of the English housewife when she throws all doors and windows open for the purpose of airing bedrooms and other rooms. It is the object aimed at by hygienists who know how persistently the organic products of respiration cling to the surfaces of the pictures and furniture of an inhabited room. And its absence explains the well-known persistent "odor humanus" of the one-room dwelling of tenement houses where the daily perflation cannot be carried on on account of the continuous occupation of the one and only room. I am, Sirs, yours faithfully,

Camden-square, N.W., Sept. 29th, 1903. JoHN F. J. SYkeS.

\section{PUBLTC CONVENIENCES.}

\section{To the Editors of THE LANCET.}

Sirs,-London is generally supposed to be ahead of other capitals in sanitary matters and the provision of public "lavatories" (urinals and water-closets) has of late years made very satisfactory advance, the underground refuges in particular leaving little to be desired as regards fittings and cleanliness. Yet in this vast city there are many regions where the wayfarer may traverse considerable distances without finding places of relief for the over-distended bladder and if they exist they are too often hidden away in obscure corners with no indication of their whereabouts. English prudishness prides itself on strict reticence on such matters, with the result that no indications are to be seen in our main thoroughfares of conveniences placed a few yards away in a side street. These remarks are based on a personal experience, probably not uncommon with sexagenarians like myself. Having to traverse Mayfair from Piccadilly to Oxford-street I could not descry a single refuge in that aristocratic quarter, but I hoped to survive until reaching the more democratic district of Marylebone, north of Oxford-street. From time immemorial there has been a simple yet sufficient urinal in Marylebone-lane opposite the Court House (where, I believe, the medical officer of health has his office), but to my disappointment this was closed, whether permanently or temporarily I know not. I remembered, however, that formerly there was another public convenience at the High-street end of the lane and thitherwards hastened my steps, only to find that that had disappeared-at any rate, I could not find it. Fortunately, the Medical Society's house in Chandos-street was within reasonable distance, and thankful, indeed, was $I$ to be a Fellow and enjoy the privilege of access to the lavatory. What I want to urge, however, is the desirability, in the interests of public health, of these indispensable institutions being so placed as to be readily found, or if hidden away that there should be some indication (on lampposts or otherwise) of their situation. A direction plate labeled "Gentlemen" or "Ladies," as the case may be, need not shock the most fastidious. If I remember rightly a green pane (without inscription) is inserted in the streetlamps of Edinburgh or Glasgow to denote the vicinity of one of these refuges, and some similar device might surely be employed with advantage in London. Some enterprising publisher might make money by bringing out a pocket-map of London with these conveniences marked. At any rate, it. would be patronised by, Yours faithfully, Sept. 28th, 1903. SEXAGENARIAN.

Liectures on Bacteriology at Plymouth.A course of lectures on bacteriology is to be given under the curriculum of the Plymouth education authority at the School of Science and Technology, Plymouth. Laboratory accommodation for practical work can be obtained by arrangement with the secretary of the South Devon and East Cornwall Hospital, Plymouth. 